University of Wollongong

Research Online

Faculty of Business - Papers (Archive)

Faculty of Business and Law

2013

International business cycles and remittance flows

Arusha V. Cooray

University of Wollongong, arusha@uow.edu.au

Debdulal Mallick

Deakin University

Follow this and additional works at: https://ro.uow.edu.au/buspapers

Part of the Business Commons

Research Online is the open access institutional repository for the University of Wollongong. For further information contact the UOW Library: research-pubs@uow.edu.au 


\title{
International business cycles and remittance flows
}

\begin{abstract}
In this paper, we study the macroeconomic determinants of remittance flows. We place particular attention to fluctuations in remittance flows over the international business cycles. Estimating a dynamic panel data model using the system-GMM method over the period 1970-2007, we document that remittance inflows decrease with home country volatility. Contrarily, remittance inflows increase with the volatility in host countries, especially for middle-income countries. Lower interest rates in host countries lead to larger remittance outflows. Trade and capital account openness are the most important factors that determine both remittance inflows and outflows. We conclude that macroeconomic factors of both home and host countries are important for understanding remittance flows.

\section{Disciplines}

Business

\section{Publication Details}

Cooray, A. V. \& Mallick, D. (2013). International business cycles and remittance flows. The BE Journal of Macroeconomics, 13 (1), 515-547.
\end{abstract}




\title{
Contributions
}

\section{Arusha Cooray and Debdulal Mallick* International business cycles and remittance flows}

\begin{abstract}
In this paper, we study the macroeconomic determinants of remittance flows. We place particular attention to fluctuations in remittance flows over the international business cycles. Estimating a dynamic panel data model using the system-GMM method over the period 1970-2007, we document that remittance inflows decrease with home country volatility. Contrarily, remittance inflows increase with the volatility in host countries, especially for middle-income countries. Lower interest rates in host countries lead to larger remittance outflows. Trade and capital account openness are the most important factors that determine both remittance inflows and outflows. We conclude that macroeconomic factors of both home and host countries are important for understanding remittance flows.
\end{abstract}

Keywords: Remittance; volatility; international business cycle; dynamic panel data.

JEL Classification Codes: C23, E32, F22, F24.

\footnotetext{
*Corresponding author: Debdulal Mallick, School of Accounting, Economics and Finance, 70 Elgar Road, Burwood, Victoria 3125, Australia, and Alfred Deakin Research Institute, e-mail: dmallic@deakin.edu.au
}

Arusha Cooray: School of Economics, University of Wollongong, Wollongong, NSW 2522, Australia

\footnotetext{
"We're stuck here while our families back home in India face a dark future with no money. I don't have a single fils (cent)" Mohan, an Indian worker in the UAE whose employer fled the country after the 2009 financial crisis. (Quoted from The Dawn Newspaper, Pakistan)
}

\section{Introduction}

Remittances account for the second largest foreign exchange inflow next to foreign direct investment and in some cases the largest (World Bank 2009). Remittance inflows to developing countries have a number of positive impacts including reduction in poverty, consumption smoothing for low-income households, economic growth, reduction in output volatility, financial sector development, and social 
and political stability. ${ }^{1}$ Although the effects of remittances are well documented, the macroeconomic determinants of remittance inflows are largely unknown.

Remittance flows ${ }^{2}$ are also closely related to international business cycles. For example, remittance inflows to low- and lower-medium-income countries increased approximately 12-fold from US\$ $19,929.98$ million to US\$ $235,685.7$ million over the 1990-2008 period, but the flows declined to US\$230,483.60 in 2009 when the developed economies were hit by recession. Total world remittance inflows also follow the same pattern increasing from US $\$ 68,542.45$ million in 1990 to US\$ 443,391.8 million in 2008 before falling to US\$ 413,678.3 in 2009.3 However, this pro-cyclicality of remittance inflows is not commonly observed in other recessions, nor is the pattern similar for low- and high-income countries (shown in Figures 1A-2D). There are few studies that examine the relation between remittance inflows and output fluctuations in remittance-sending countries but these studies are limited to a pair of one home (remittance-receiving) and one host (remittance-sending) country. ${ }^{4}$ Shorter time series do not allow one to incorporate business cycle information of all host countries (number of observations for a home country is smaller than number of host countries). The problem becomes more acute at the cross-country level.

In this paper, we study the macroeconomic determinants of remittance flows. We place particular attention to fluctuations in remittance flows over the international business cycles. More specifically, we investigate the effects of growth volatility in home and host countries on remittance inflows and outflows at the cross-country level. ${ }^{5}$ This is important because business cycles increase volatility and thus increase uncertainty in both home and host countries, which have profound effects on remittance flows.

1 For discussions on the effects of remittances, see, among others, Adams and Page (2003), Kapur (2005), Lueth and Ruiz-Arranz (2008), Chami et al. (2009), Giuliano and Ruiz-Arranz (2009), Frankel (2009) and Mundaca (2009).

2 Remittances are defined as the sum of workers' remittances, compensation of employees and migrants' transfers (World Bank 2009). Although, this definition is not beyond criticism (Chami et al. 2008), it is based on the data availability at the cross-country level and is also frequently used in the literature. For example, Bugamelli and Paternò (2011) use the same definition in their study of 60 emerging and developing economies and document a negative effect of remittances on output growth volatility.

3 Authors' own calculation from the World Bank data.

4 For example, Sayan (2004), Akkoyunlu and Kholodilin (2008) and Sayan and Tekin-Koru (2008) have studied the case of Turkey and Germany, and Sayan and Tekin-Koru (2008) and Vargas-Silva (2008) have studied the case of Mexico and the USA.

5 Given that growth is negatively related to volatility (since the seminal work of Ramey and Ramey 1995, there is a large literature on this relationship), we consider business cycle in terms of the second moment. 


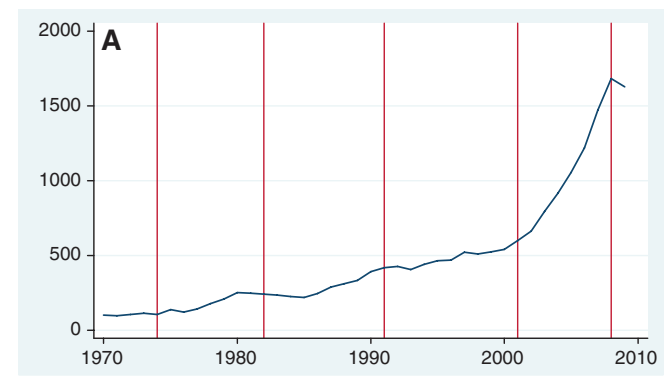

Figure 1A Average remittance inflows $(1970=100)$.

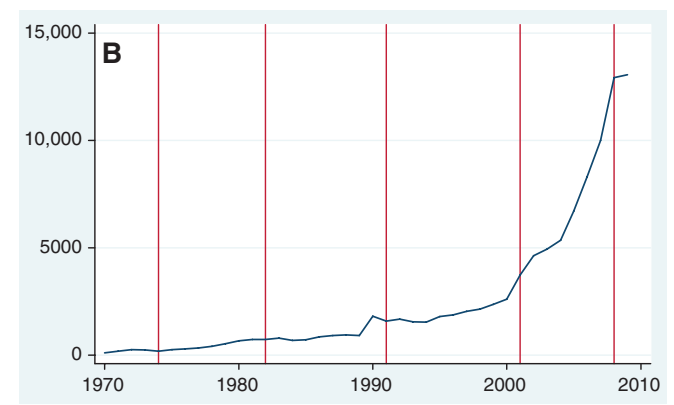

Figure 1B Average remittance inflows to low-income countries (1970=100).

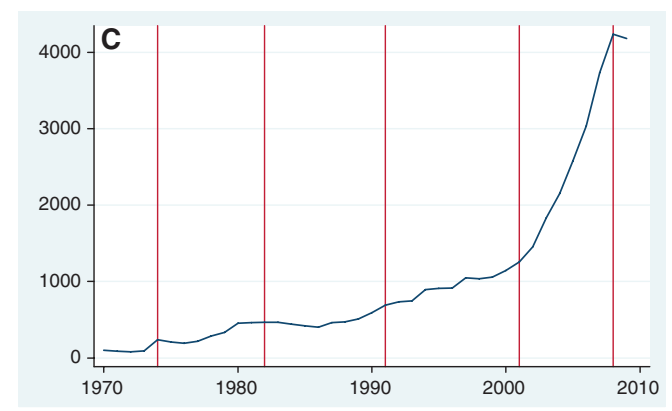

Figure 1C Average remittance inflows to middle-income countries (1970=100).

Since output volatility of all host countries from which a home country receives remittances is important but difficult to capture in a small sample, we employ an innovative approach to capture such effects. For each home country, we construct a time series of the rest-of-the-world (ROW) volatility and include it as an explanatory variable in the regression. This ROW volatility is the weighted average of real 


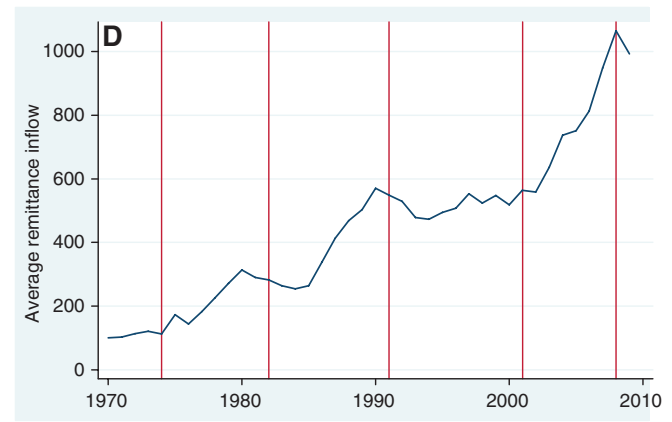

Figure 1D Average remittance inflows to high-income countries (1970=100).

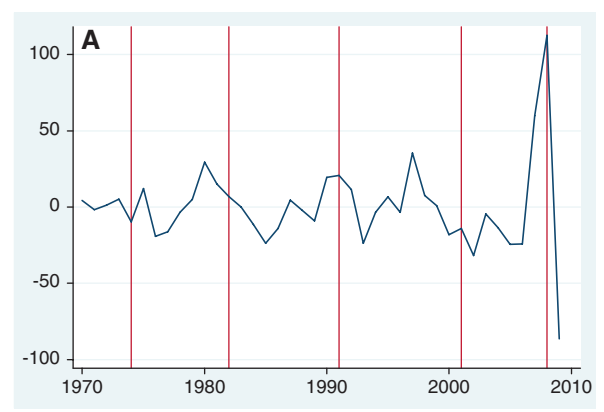

Figure 2A Average remittance inflows: HP filtered sereis.

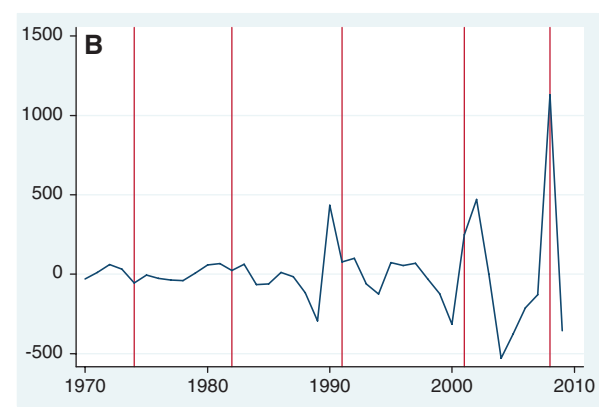

Figure 2B Average remittance inflows to low-income countries: HP filtered series.

GDP growth volatility of all host countries from where a home country receives remittances. The weight attached to a host country is its share in total remittance inflows to the home country. To check the robustness of the results, we construct an alternative weight attached to a host country as its share in the stock of migrants 


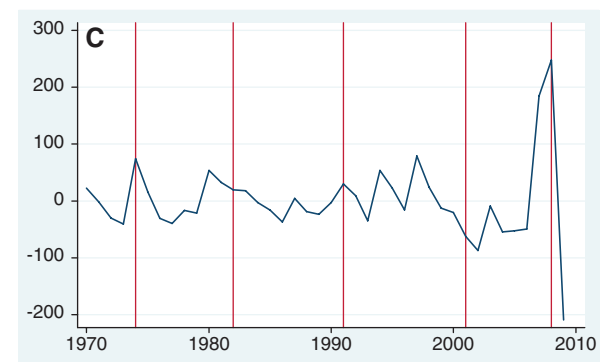

Figure 2C Average remittance inflows to middle-income countries: HP filtered series.

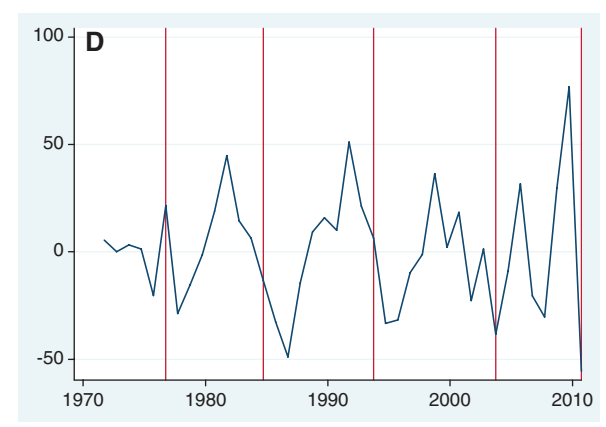

Figure 2D Average remittance inflows to high-income countries: HP filtered series.

from the home country. We also estimate the determinants of remittance outflows to understand other macroeconomic factors of host countries that influence remittance inflows to home countries. For each host country, a similar time series of the rest-of-the-world (ROW) volatility is constructed as the weighted average of real GDP growth volatility of all home countries to which it sends remittances. The weight attached to a home country is its share in total remittance outflows from the host country. We check for robustness by constructing an alternative weight attached to a home country as its share in the stock of migrants in the host country. Finally, we estimate the determinants of net remittance flows.

Using data for the period 1970-2007 for 116 countries, we estimate a dynamic panel data model using the system-GMM method developed by Arellano and Bover (1995) and Blundell and Bond (1998) designed for datasets with many cross-sections and few time periods. The dependent variable(s) is (are) the logarithm of the ratio of remittance inflows (outflows and net flows) to GDP. The explanatory variables are the relevant macroeconomic factors considered to determine remittance flows such as growth volatility at home and the ROW, trade and capital account openness, inflation and exchange rate volatility, money supply, investment and 
institutional quality. The volatility of a series has been calculated as the non-overlapping 5-year standard deviation; hence, other data are compressed by taking 5-year averages. ${ }^{6}$ Our estimation accounts for the endogeneity of home country volatility and other macroeconomic determinants included in the regression.

The results show that remittance inflows decrease with home country volatility which is consistent with the investment motive of remittance inflows. But remittance inflows increase with the volatility in host countries, especially for middle income countries supporting the risk aversion (or insurance) motive of migrant workers (Galor and Stark 1990, Amuedo-Dorantes and Pozo 2006). The results are also consistent with Giuliano and Ruiz-Arranz (2009) who document pro-cyclicality of remittance inflows, and contrast with Frankel (2009) who finds that remittances are counter-cyclical with respect to income in the home country while pro-cyclical with respect to income in the host country. Lower interest rates (higher money supply) increase remittance outflows from a host country. Both remittance outflows and net flows are uncorrelated to the volatility in host and home countries. However, for middle-income countries, remittance outflows increase with volatility and lack of investment opportunity in host countries. Trade and capital account openness are the most important factors that determine remittance inflows, outflows and net flows. The overall results suggest that remittance flows are influenced by macroeconomic conditions in both home and host countries.

The rest of the paper proceeds as follows. Section 2 reviews the related literature and develops the motivations of the paper. Section 3 describes our approach to calculate the rest-of-the-world volatility. The estimation method is discussed in Section 4. The empirical findings are presented in Section 5. Finally, Section 6 concludes.

\section{Related literature and motivation of the study}

\subsection{Literature review}

Much of the theoretical work on remittances has been devoted to the primary motive of migrants to remit. Among the motives put forward are altruism (Banerjee 1984), insurance (Rosenzweig 1988), investment (Lucas and Stark 1985), inheritance (Hoddinott 1994), risk diversification (Stark and Lehvari 1982, de la Brière et al. 2002, Rapoport and Docquier 2006), and compensating family for past expenditure (Stark and Lucas 1988). There is, however, no agreement in the litera-

6 This approach of taking 5-year averages is also standard in the volatility-growth literature. Examples include, among others, Martin and Rogers (2000), Kneller and Young (2001) and Cavalcanti, Mohaddes and Raissi (2012). 
ture as to the relative importance of migrants' motives to remit. Since the work of Lucas and Stark (1985), many studies have recognized that several motives could co-exist simultaneously. However, the motive to remit is also closely related to the business cycles of both home and host countries.

If remittances are sent with an altruistic motive, they are likely to be countercyclical with respect to the output in the home country. The volume of remittance inflows will increase during an economic downturn in the home country, compensating families for the fall in income (Agarwal and Horowitz 2002). On the other hand, if remittances are sent with a profit-driven motive, such as investment or inheritance, they are likely to be pro-cyclical. Under this motive, the volume of remittance inflows will decline during an economic downturn in the home country (Giuliano and Ruiz-Arranz 2009). However, an increase in the migrants' income in the host country will lead to an increase in remittances under both motives.

Another strand of literature, although not in copious amounts, stresses the risk aversion (insurance) motive of migrant workers. For example, when the downswing of business cycles in host countries hit hard, migrants are more likely to return to their home countries (Galor and Stark 1990) and, as a consequence, remittance inflows increase because the migrant workers carry their savings with them. This argument is also reinforced by the fact that migrant workers make more precautionary savings than native workers (Dustmann 1997). These theoretical arguments are also supported by empirical findings. For example, AmuedoDorantes and Pozo (2006), examining the case of Mexican migrants in the US, document that an increase in income risk in the host country significantly raises both the propensity and proportion of labor earnings sent home for insurance.?

There are several empirical studies conducted at the macroeconomic level that investigate the relationship between remittance inflows and output fluctuations in the home country for a panel of countries. Lueth and Ruiz-Arranz (2008) use a dataset of bilateral remittance flows to 11 recipient countries from the major sending countries for 9 years to investigate the factors determining the cyclical properties of remittances, the motives to remit and ability to smooth shocks. They document that remittances do not appear to increase in the event of a negative shock but rather move with the business cycle in the home country, suggesting that remittances may not play a large role in smoothing a negative shock. Giuliano and Ruiz-Arranz (2009) also report the pro-cyclicality of remittance inflows in 100 countries for the period 1975-2002. These results are consistent with the investment motive of remittance flows.

On the other hand, Frankel (2009) finds that remittances are counter-cyclical with respect to income in the home country while pro-cyclical with respect to

7 Another motive closely tied to these motives and is based on the migration networks literature is the options motive (for a detailed discussion, see Roberts and Morris 2003). 
income in the host country, thus suggesting the consumption smoothing hypothesis. Similar stabilization effects are also documented by Chami et al. (2009) and Jackman et al. (2009). Neagu and Schiff (2009) compare the stability, cyclicality, and stabilizing effects of remittances with foreign direct investment and official development assistance in 116 countries over the 1980-2007 period. They find that remittances are more stable than FDI in $72 \%$ of the countries in their sample. They emphasize the importance of separating the counter-cyclicality from the stabilizing effect, as the former does not always imply the latter. Barajas et al. (2010) document that remittance inflows to the African countries have fallen between 3\% and $14 \%$ as a result of the declining emigration to Europe during the recent recession.

A number of time-series studies investigate the remittance response to the output of both host and home countries but these are limited to remittance flows between a pair of countries. For example, Sayan (2004) employs quarterly time series data for 1987-2001, and documents cross correlations between the cyclical components of real GDP and remittances from Germany to Turkey. He finds that remittance receipts to Turkey are pro-cyclical with Turkish output, but acyclical with German output. Akkoyunlu and Kholodilin (2008), on the other hand, find that during 1962-2004 the volume of remittances sent by Turkish workers in Germany varied positively with changes in German output rather than Turkish output. Sayan and Tekin-Koru (2008) support Sayan (2004) in that remittance receipts to Turkey from Germany are pro-cyclical. These authors also document that remittance inflows to Mexico from the USA are counter-cyclical. Their results are supported by Durdu and Sayan (2008) who calibrate a small open economy model to the data for Mexico and Turkey over the 1987-2004 period and find that remittance inflows dampen business cycles in Mexico, but amplify those in Turkey. Vargas-Silva (2008) also documents that remittances vary counter-cyclically with Mexico's output.

\subsection{Motivation}

The above discussions illustrate that although there is a large literature on remittances, research on macroeconomic determinants of remittance inflows at the cross-country level is scant. Furthermore, volatility in host countries is important for understanding remittance inflows to the home country. More generally, international business cycles have an effect on remittance flows. However, this important link at the cross-country level has not received attention.

To demonstrate the relation between international business cycles and remittance inflows, we plot the average remittance inflows over the period 1970-2009 and look particularly at the periods of recessions in the USA defined by the 
National Bureau of Economic Research. ${ }^{8}$ Average world remittance inflows are calculated as the total amount of annual remittance inflows in the world divided by the number of home countries. ${ }^{9}$ We normalize the average inflow series by its value in 1970. Vertical lines for the years 1974, 1982, 1991, 2001 and 2008 are drawn to mark the recession years in the USA.

Average remittance flows for the world are displayed in Figure 1A. There is a trend of modest increase in average remittance inflows over the sample period with a sharp increase since 2001 followed by a dip in 2009. During other recessions, average remittance inflows either remained the same (1974 and 1982 recessions) or increased slightly compared to previous periods. Average remittance inflows declined during the first Gulf war. We also observe a similar pattern for low- and medium-income countries displayed in Figures $1 \mathrm{~B}$ and 1C, respectively (countries are defined as low-, medium- and high-income according to the World Bank classification). Remittance inflows fluctuate most for high-income countries (Figure 1D). The cyclical behavior can also be understood from the series detrended by the Hodrick and Prescott (1997) filter. These are presented in Figures 2A-2D. The figures display that the cyclical behavior of remittance inflows varies across country income groups. The high-come countries display the most cyclicality (Figure 2D), while the low-income countries display the least (Figure 2A). The figures and discussions above suggest that remittance flows fluctuate over the business cycles in host countries and therefore, such information is crucial for understanding remittance inflows to home countries.

\section{Calculation of the rest-of-the-world volatility}

As mentioned earlier, the available remittance series for short period do not permit one to incorporate the information of all host countries. The problem is more acute for studies at the cross-country level. We employ an innovative approach to account for host country information. For each home country, we construct a rest-of-the-world (ROW) volatility series exploiting the information on growth volatility in all host countries and include it as an explanatory variable in the regression. Moreover, we estimate an additional equation for the determinants of

8 Business cycles in developed countries are, to a large extent, correlated (Ambler, Cardia, and Zimmermann 2004) although there may be divergence at some points in time. Given that these countries are usually remittance senders, it is reasonable to consider that other remittance sending countries follow similar business cycle patterns as the USA.

9 Total world remittance inflows are also informative but the number of home countries differ across years in the dataset. 
remittance outflows to understand the macroeconomic factors of host countries responsible for remittance inflows to home countries. For the latter specification, we construct a similar ROW volatility series for each host country exploiting the information of growth volatility in all home countries.

The two ROW volatility series are constructed as follows. For each sample country, we first calculate 5-year non-overlapping standard deviation of the growth rate of per capita real GDP de-trended by the Hodrick Prescott (HP) filter. The filtering retains only the cyclical component of the growth series. ${ }^{10}$ We use a smoothing parameter of 6.25 as we deal with annual data. ${ }^{11}$ For a home country $i$, the ROW volatility in period (interval) $t$ is the weighted average of the volatility of all host countries, and is defined as:

$$
(\text { ROW volatility })_{i, t}=\sum_{j} \sigma_{j, t} S_{i j}, \forall i \neq j,
$$

where $\sigma_{j, t}$ is the growth volatility in host country $j$ in period $t$ calculated by the method mentioned above. The weight is calculated as $s_{i j}=R_{i j} / \sum_{j} R_{i j}$, where $R_{i j}$ is remittance inflows to home country $i$ from host country $j$. This may be a limitation in our ROW volatility index because the weight $s_{i j}$ has been treated as time invariant. At the cross-country level, remittance inflow and outflow data are reported at the aggregate level without their sources and destinations. For a home country, the sources of annual inflows are not available. Similarly, for a host country, the destinations of annual outflows are not available. This detailed inflow-outflow information is available only for 2005 (Ratha and Shaw 2007) which we use to calculate $s_{i j}$. To check the robustness of the results, an alternative weight is also calculated as $s_{i j}^{\prime}=M_{i j} / \sum_{j} M_{i j}$, where $M_{i j}$ is the stock of home country $i$ 's migrants to host country $j$. It is important to mention that disaggregated information on the stock of migrants for all host-home combinations is also not available on an annual basis. However, it is conceivable that for a home country the share of migrants in different host countries changes slowly over time. Therefore, we use the weight $s_{i j}$ for 2005 to calculate the time series for the ROW volatility for our benchmark estimation because remittance flows contain information on both

10 Some papers estimate volatility as the standard deviation of the series rather than that of the detrended series. The difference between the two approaches lies in the treatment of the trend growth rate. The standard deviation of the growth series implicitly assumes a constant trend growth, while the standard deviation of the detrended series allows the trend to follow a timedependent process (Hnatkovska and Loayza 2005, p. 74-75).

11 This is based on the recommendation by Ravn and Uhlig (2002, p. 371) who show that the parameter should be adjusted approximately with the fourth power of the frequency change. 
migrant stock and their income. For robustness checks, we use the weights $s_{i j}^{\prime}$ for both 2005 and 2010.

We construct a similar ROW volatility series for each host country $h$, as

$$
(\text { ROW volatility })_{h, t}=\sum_{l} \sigma_{l, t} s_{h l}, \forall h \neq l,
$$

where $\sigma_{l, t}$ is the growth volatility in home country $l$ in period $t$. The weight is calculated as $s_{h l}=R_{h l} / \sum_{h} R_{h l}$, where $R_{h l}$ is the remittance outflow to home country $l$ from host country $h$. As before, to check the robustness of the results, an alternative weight is also calculated as $s_{h l}^{\prime}=M_{h l} / \sum_{h} M_{h l}$, where $M_{h l}$ is the stock of migrants in the host country $h$ from the home country $l$. We calculate $s_{h l}$ for 2005 to construct the ROW volatility series for the benchmark estimation and $s_{h l}^{\prime}$ for 2005 and 2010 for robustness checks.

\section{Estimation strategy}

We estimate the following dynamic panel model:

$$
y_{i, t}=\alpha+\mu_{\mathrm{I}}+\lambda_{t}+\delta y_{i, t-1}+\boldsymbol{\beta} \mathbf{X}_{\mathbf{i}, \mathbf{t}}+\varepsilon_{i, t},
$$

where $y_{i, t}$ is the log of the ratio of remittance inflows (outflows and net flows) to GDP for country $i$ in period (interval) $t$. $\mu_{i}$ represents country fixed effects, $\lambda_{t}$ denotes time fixed effects which are captured by time dummies, and the error term $\varepsilon_{i, t}$ is assumed not to be correlated across countries. The following variables in the $\mathbf{X}_{\mathrm{i}, \mathrm{t}}$ vector have been chosen based on both theory and the empirical evidence in the literature.

- Growth volatility (log): This is a 5-year non-overlapping standard deviation of the growth rate of per capita real GDP de-trended by the HP filter. This variable is included to explore the effect of economic uncertainty ${ }^{12}$ on (and business cycle properties of) remittance inflows (outflows and net flows).

- ROW volatility (log): This variable accounts for the volatility in the host/ home countries. If remittance inflows and net flows are the dependent variables, the ROW volatility is given by equation (1), and if remittance outflow is the dependent variable, it is given by equation (2).

- Inflation volatility (log): This variable has been calculated as a 5-year non-overlapping standard deviation of the CPI inflation rate and is intended to capture

12 There is a difference between volatility and uncertainty. Volatility measures both the predictable and unpredictable changes, while uncertainty measures only the unpredictable changes (Ramey and Ramey 1995). We do not make this distinction here. 
the risk and uncertainty caused by inflation. Higher inflation volatility can both be positively and negatively related to remittance flows depending on the motive to remit. For example, higher inflation volatility slows down growth and investment thus decreasing remittance flows. Conversely, higher inflation volatility increases the economic burden on the migrant workers' family back home thus increasing remittances for family support (Lueth and Ruiz-Arranz 2008).

- Exchange rate volatility (log): This variable has also been calculated as a 5-year non-overlapping standard deviation of the nominal exchange rate with the US dollar and is intended to capture the risk and uncertainty caused by exchange rate movements. The value of remittances in domestic currency depends on the market exchange rate, and volatile exchange rates increase the risk and uncertainty which in turn influence the migrant workers' decision to remit (Lianos 1997, Higgins et al. 2004).

- Capital account openness: This variable is constructed by Chinn and Ito (2008). The higher the capital account openness, the lower is the barrier to capital flows across borders, and therefore, more remittances will flow through official channels. ${ }^{13}$

- Trade openness: This is the sum of exports and imports relative to GDP. An open economy interacts more with the rest of the world that creates greater scope for migration for its citizens (Chami et al. 2009).

- Investment-GDP ratio: Investment-GDP ratio is intended to account for the investment climate that has been found to be important for remittance flows (Ratha 2005); this variable has also been regarded as a proxy for financial infrastructure that also determines remittance flows (Amuedo-Dorantes and Pozo 2006). As also discussed in Section 2.2, one of the motives for remitting is investment, which is supported in the work of Durdu and Sayan (2008) and Amuedo-Dorantes and Pozo (2006).

- Money supply: This is represented by the ratio of M2 to GDP. In macroeconomic research, the M2-GDP ratio is also used as a proxy for financial development. Although the ratio of private credit to GDP may be a better a proxy, it reduces the number of sample countries in our data. In addition, money supply is nega-

13 The Chinn and Ito (2008) capital account openness index is based on the following information regarding actual restrictions on capital flows: i) the presence of multiple exchange rates, ii) restrictions on current account transactions, iii) restrictions on capital account transactions, and iv) the requirement of the surrender of export proceeds. A possible alternative to capital account openness could be the financial integration index constructed by Lane and Milesi-Ferretti (2007). However, this is a price based measure that also reflects changes in the macroeconomic conditions even in the absence of any regulatory change on capital account transactions (endnote 5 in Chinn and Ito, 2008). The macroeconomic determinants included in our equation (3) capture the effect of the financial integration index. 
tively related to the interest rate. A higher interest rate in the home country is expected to increase remittance inflows, while a higher interest rate in the host country is expected to decrease remittance outflows (Lueth and Ruiz-Arranz 2008, Chami et al. 2009). It is important to note that interest rates are not comparable across countries because different countries report different interest rates. On the other hand, the M2-GDP ratio is comparable across countries. ${ }^{14}$

- Institutions: Remittance flows depend on a country's investment opportunities and social welfare systems, which in turn depend on its level of institutional development. Moreover, migrants from a country with oppressive institutions prefer to settle permanently in the host country and as a result remit less to the home country (Chami et al. 2009). We use the Polity2 score as a proxy for institutions. This variable captures the regime authority spectrum on a 21-point scale ranging from -10 (hereditary monarchy) to +10 (consolidated democracy). It examines concomitant qualities of democratic and autocratic authority in governing institutions, rather than discreet and mutually exclusive forms of governance.

- Initial real GDP per capita: This variable accounts for the income level of a country. The motives for remitting vary across countries of different income categories.

In the literature, both inflation and exchange rates have alternatively been used in terms of either the first or the second moment. Several studies, including Lianos (1997) and El Sakka and McNabb (1999), incorporate them in the regression as the first moment (level or change). Studies that include them as the second moment (volatility) are mentioned above. The two moments may capture the different information about risks associated with remittance flows, therefore, we also estimate equation (3) augmented by (changes in) these two variables. ${ }^{15}$

The reason for the dynamic specification is that the remittance-GDP ratio is quite persistent (as confirmed in our regression results; also see Gupta 2005). The lagged dependent variable is also intended to account for the effects of networks on remittance flows. It is important to mention that remittance flows are directly related to the stock of migrants. Migrants remit, along with money, important information about job opportunities and income prospects for potential migrants; therefore, potential migrants prefer to migrate

14 Several other variables, such as the interest rate differential between the home and host countries (Faini 1994, El Sakka and McNabb 1999), or the federal fund rate (Vargas-Silva and Huang 2006) have also been included as determinants of remittance flows. However, they cannot be applied at the cross-country level.

15 An anonymous referee has also recommended this exercise. 
to a country where more migrants from their country of origin reside. Finding jobs become easier for new migrants in the host country due to networks with existing migrants.

The ROW volatility variable is treated as exogenous because world economic fluctuations are not influenced by a single home or host country. Polity2 is also treated as exogenous since we take its initial value for each interval. The investment ratio, growth volatility, inflation, and exchange rates are endogenous because they are likely to be influenced by remittance flows. Money supply is also treated as endogenous because remittance flows exert pressure on the exchange rate and the central bank has to intervene in the domestic money market even if the exchange rate is not entirely fixed. The central bank may also need to intervene if remittance flows put upward pressure on the inflation rate. It is not clear whether trade and capital account openness are influenced by remittance flows. However, it is likely that a host country may not attract migrant workers unless it removes constraints on capital outflows (Chami et al. 2009). It is also likely that remittance inflows pressurize a home country to open up its capital market when migrants wish to invest in the portfolio market. Historically, workers migrate to countries having close cultural, religious or trade links with the home country. We estimate the models treating both openness variables as endogenous.

The sample period is 1970-2007 because remittance data are available starting from 1970 and data for some explanatory variables are available up to $2007 .{ }^{16}$ Since the volatility measures are calculated as 5 year non-overlapping standard deviations, other variables are averaged over 5 years except initial GDP and Polity2 for which initial values of each interval are taken. Therefore, we have seven time intervals - 1970-74, 75-79, 80-84, 85-89, 90-94, 95-99 and 2000-2007. Remittance (and also other explanatory variables) data are not available for many countries for different time periods, therefore we deal with an unbalanced panel data set. The number of countries differs in different specifications depending on the dependent variable and the choice of the independent variables.

We estimate equation (3) by the Arellano and Bover (1995)/Blundell and Bond (1998) system-GMM method designed for datasets with many cross-sections and few time periods. ${ }^{17}$ This method assumes that there is no autocorrelation in the errors and requires the initial condition that the panel-level effects be

16 The following are the sources of data: i) World Bank: remittance flows, migration stock, openness (the ratio of exports plus imports to GDP), nominal exchange rate, M2-GDP ratio, and CPI inflation; ii) Penn World Table 6.2: real GDP, and investment-GDP ratio; iii) Chinn and Ito (2008): capital account openness; iv) Polity IV Project (Political Regime Characteristics and Transitions, 1800-2007): Polity2.

17 Roodman (2006) provides an excellent user guide for dynamic panel data estimation. In this paper, we estimate using the "xtdpdsys" command in STATA. 
uncorrelated with the first difference of the first observation of the dependent variable. We report the Arellano and Bond (1991) test statistic for second-order serial correlation in the first-differenced errors. The estimators are consistent only if the moment conditions are valid. We test the validity of the overidentifying moment conditions by the Hansen statistic.

\section{Results}

We start with a brief discussion of the descriptive statistics of the variables used in the regressions. The results are presented in Table 1.

The average remittance inflows are about 4\% of GDP over the sample period. They are higher in medium-income countries (around 5\%) followed by low- and high-income countries (around 3\% and $<1 \%$, respectively). The average remittance outflows, on the other hand, are only $1 \%$ of GDP. This result is conceivable given that remittances usually flow from high- to low- and middle-income countries. Average growth volatility decreases with the income level. The ROW volatility for home countries is about 1.8 times larger for low- compared to highincome countries when the weight is calculated using the migrant stock but it is about 1.4 times larger when the weight is calculated using remittance flows. The average value of ROW volatility is very close at 1.9 and 1.8 for the above two weights, respectively. Conversely, the ROW volatility for host countries differs considerably for the two weights. For example, it is about 3.5 times larger for high-compared to low-income countries when the weight is calculated using the remittance flows but lower for high- compared to low-income countries if the weight is calculated using the migrant stock. In high-income countries, capital account and trade are more open, the exchange rate is less volatile, the ratio of M2 to GDP is larger and institutional quality is higher compared to middle- and low-income countries.

The correlation between any pair of explanatory variables is low (not reported). The highest correlation is between money supply and investment-GDP ratio (0.52) followed by money supply and inflation volatility $(-0.41)$.

Before turning to the regression results, it is important to mention that only those results are retained and presented for which the Hansen test for overidentifying restrictions and $\operatorname{AR}(2)$ test of the first-differenced residual are valid and the number of instruments is less than the number of groups (countries). Only two lags of both dependent and independent variables are used as instruments in all regressions so that the number of instruments does not exceed the number of countries. 


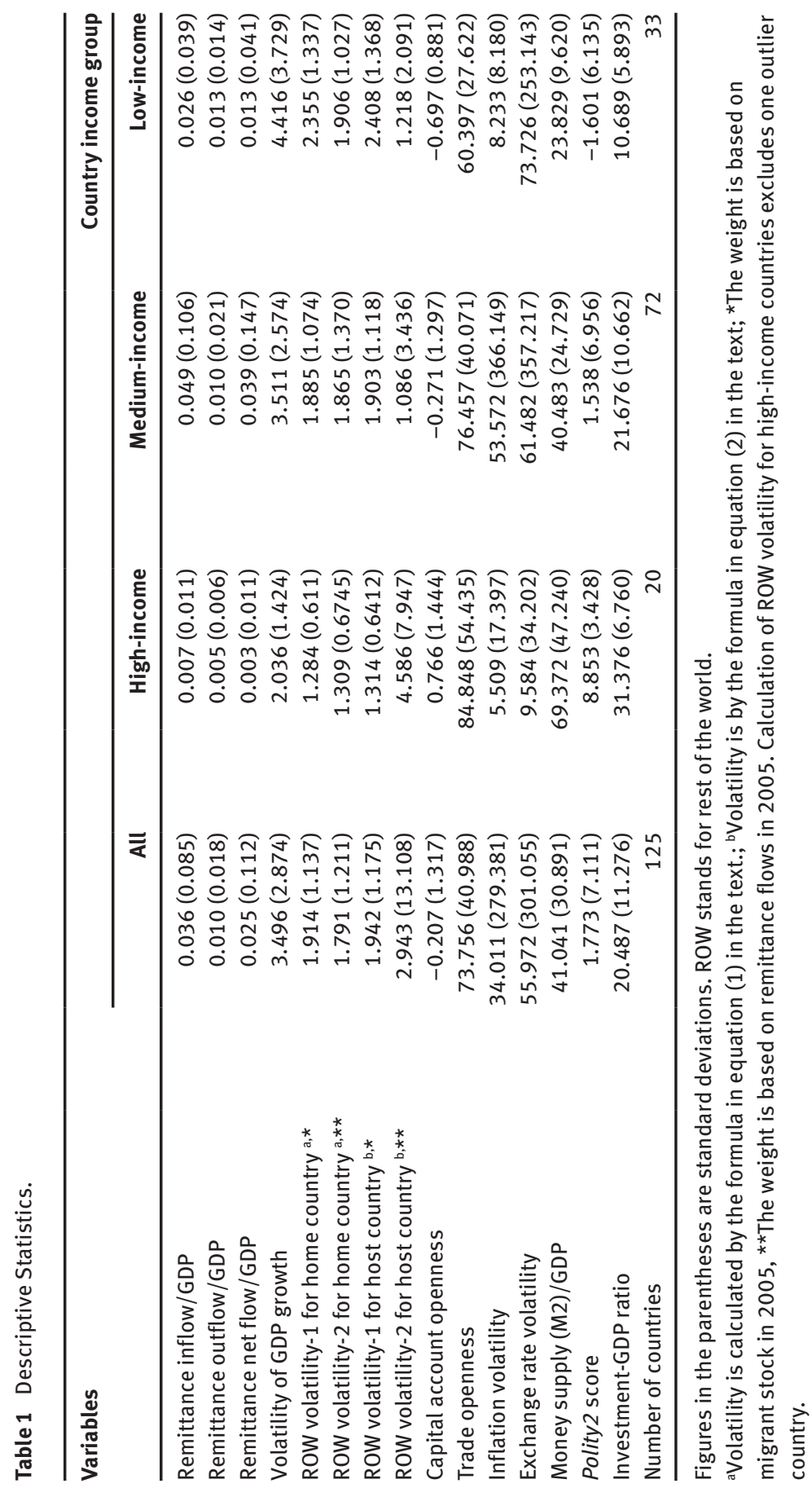




\subsection{Determinants of remittance inflows}

The results for the determinants of remittance inflows are presented in Table 2. In columns 1 and 2, we present the results when ROW volatility is constructed using the weight from the remittance share in 2005. The remittance-GDP ratio is decreasing with growth volatility in the home country. Remittance inflows decrease by about $6 \%$ for a 10\% increase in growth volatility. This result suggests that economic uncertainty in home countries reduces remittance inflows and therefore supports the investment motive (it can alternatively be interpreted as the pro-cyclical behavior of remittance inflows). On the other hand, remittance inflows increase with inflation volatility, which suggests the altruistic motive of the migrants. Remittance inflows increase with the ROW volatility; the coefficient is 0.35 suggesting about a 3.5\% increase in remittance inflows for a $10 \%$ increase in the ROW volatility. ${ }^{18}$ This result suggests that economic uncertainty in host countries increases remittance inflows to home countries (it can alternatively be interpreted as the counter-cyclical behavior of remittance inflows with respect to fluctuations in host countries), which in turn supports the risk aversion motive of migrant workers. Both trade and capital account openness increase remittance inflows.

Given that the number of sample countries is small, a separate disaggregated analysis by income group is problematic because the number of instruments exceeds the number of countries. ${ }^{19}$ To address this problem, the (aggregate) ROW volatility is replaced by the ROW volatility for the three income groups (i.e., the ROW volatility multiplied by the three income group dummies). The results, presented in column 2, do not change from those presented in column 1; however, the ROW volatility is significant for only middle- and low-income countries. For middle-income countries, the remittance-GDP ratio increases by about $5 \%$ for a $10 \%$ increase in the ROW volatility.

Columns 3 and 4 replicate the estimation in columns 1 and 2 with the ROW volatility constructed using the weight from the migrant stock in 2005 . The results are robust both in terms of the magnitude of the coefficients and statistical significance, except that the ROW volatility is significant only for the middle-income countries. The middle-income countries constitute more than $50 \%$ of all sample countries and the remittance-GDP ratio is also the largest for them. Although the

18 The growth volatility of a country may depend on the ROW volatility. However, in the data, the correlation between the two volatilities is only 0.14 .

19 However, we conduct a separate analysis in Section 5.4 only for the middle-income countries for which a relatively large number of countries are available. In some specifications, the number of instruments exceeds the number of countries. 


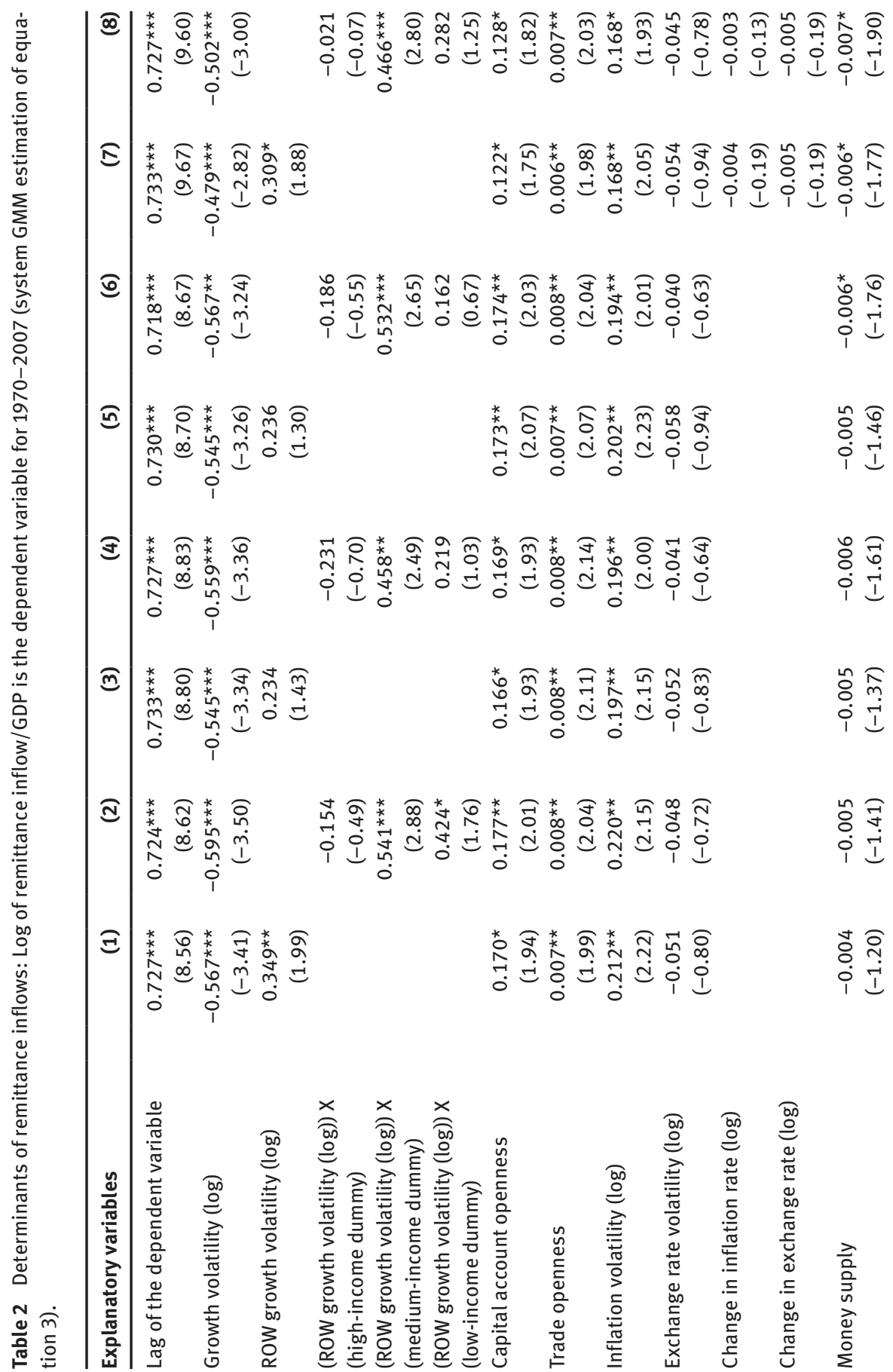




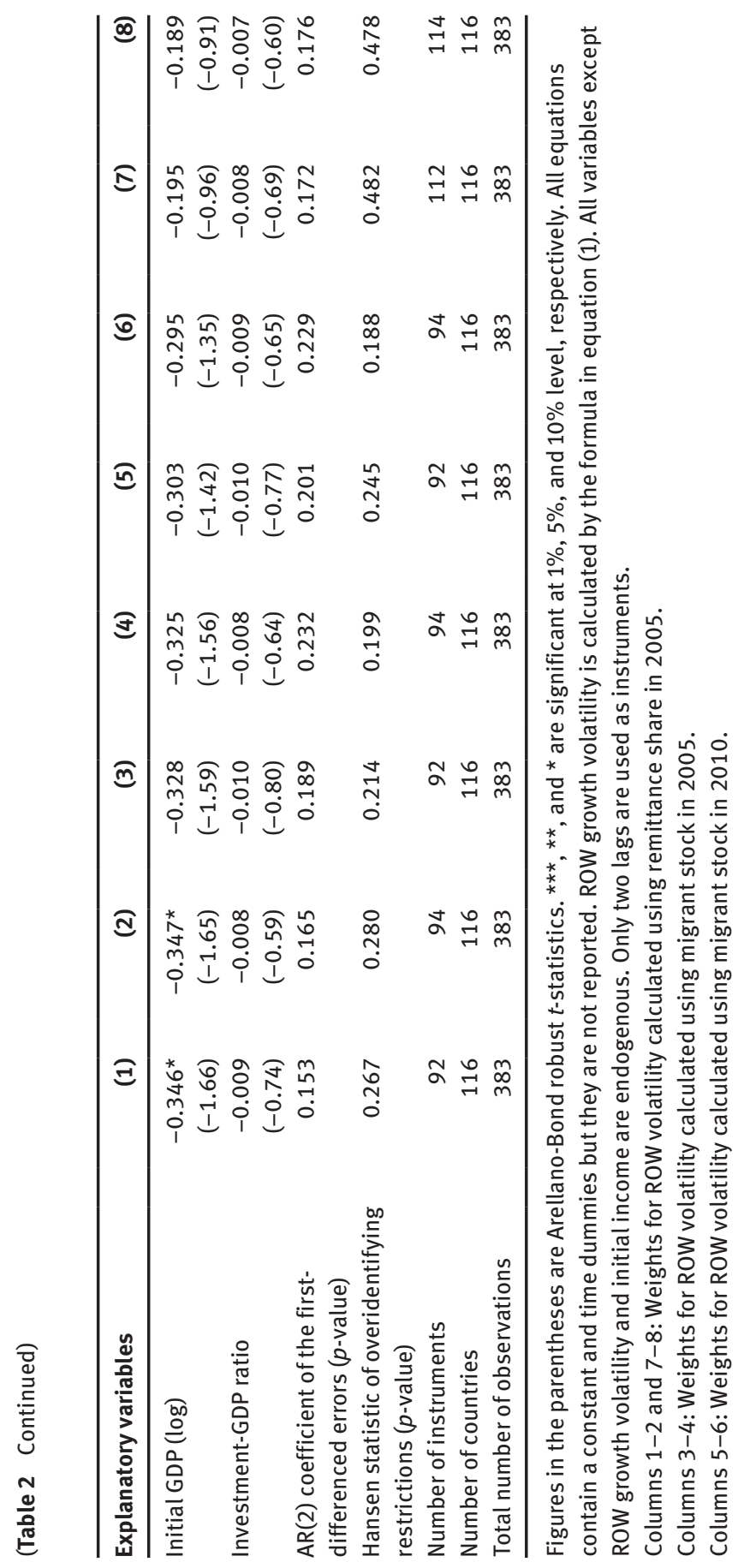


low-income countries are also remittance receivers, the middle-income countries possess a better investment climate and are also more open to trade and capital flows (our Table 1; see also Ratha 2005), therefore remittance inflows in the latter group of countries are influenced more by the ROW volatility.

To further check the robustness of the results, the ROW volatility has been calculated using the weight from the migrant stock in 2010. The results are presented in columns 5 and 6 . All the results are robust both in terms of the magnitude of the coefficients and statistical significance. ${ }^{20}$

We now include changes in inflation and exchange rate in the regression. The results using the benchmark ROW volatility are presented in columns 7 and 8 . It is evident that the previous results are robust to inclusion of these two variables and their coefficients are insignificant.

\subsection{Determinants of remittance outflows}

Now we investigate the determinants of remittance outflows. Note that the sample countries do not match the countries for remittance inflows because several countries report either remittance inflows or outflows. Moreover, remittance outflow data are available for fewer countries; therefore, the 1980-2007 period has been retained to reduce the number of instruments. This can also be justified from Figures 1A-1D, which shows that average remittance flows were quite low during 1970-1980.

The results are presented in Table 3. The ROW volatility for the host country is now estimated by the formula in equation (2). Columns 1 and 2 present the results when the remittance share for 2005 is used as the weight to calculate ROW volatility. For both aggregate and disaggregated income levels, money supply is the only factor that significantly affects remittance outflows. Higher money supply in the host country increases remittance outflows. This result is quite intuitive because higher money supply implies a lower interest rate that causes larger remittance outflows from the host country. This is consistent with the investment motive. Trade openness is significant but robust across specifications when the migrant stock in 2010 is used as the weight for the ROW volatility (columns 5 and 6). The host country volatility and ROW volatility are insignificant both in the aggregate and disaggregated models. The results remain robust if the regression equation is augmented by changes in the inflation and exchange rate (columns 7 and 8). Both the changes and volatility of these two variables are insignificant.

20 Although the results are robust, they should be treated with caution because our sample period spans until 2007, and the great recession may have changed the migration stock in 2010. 


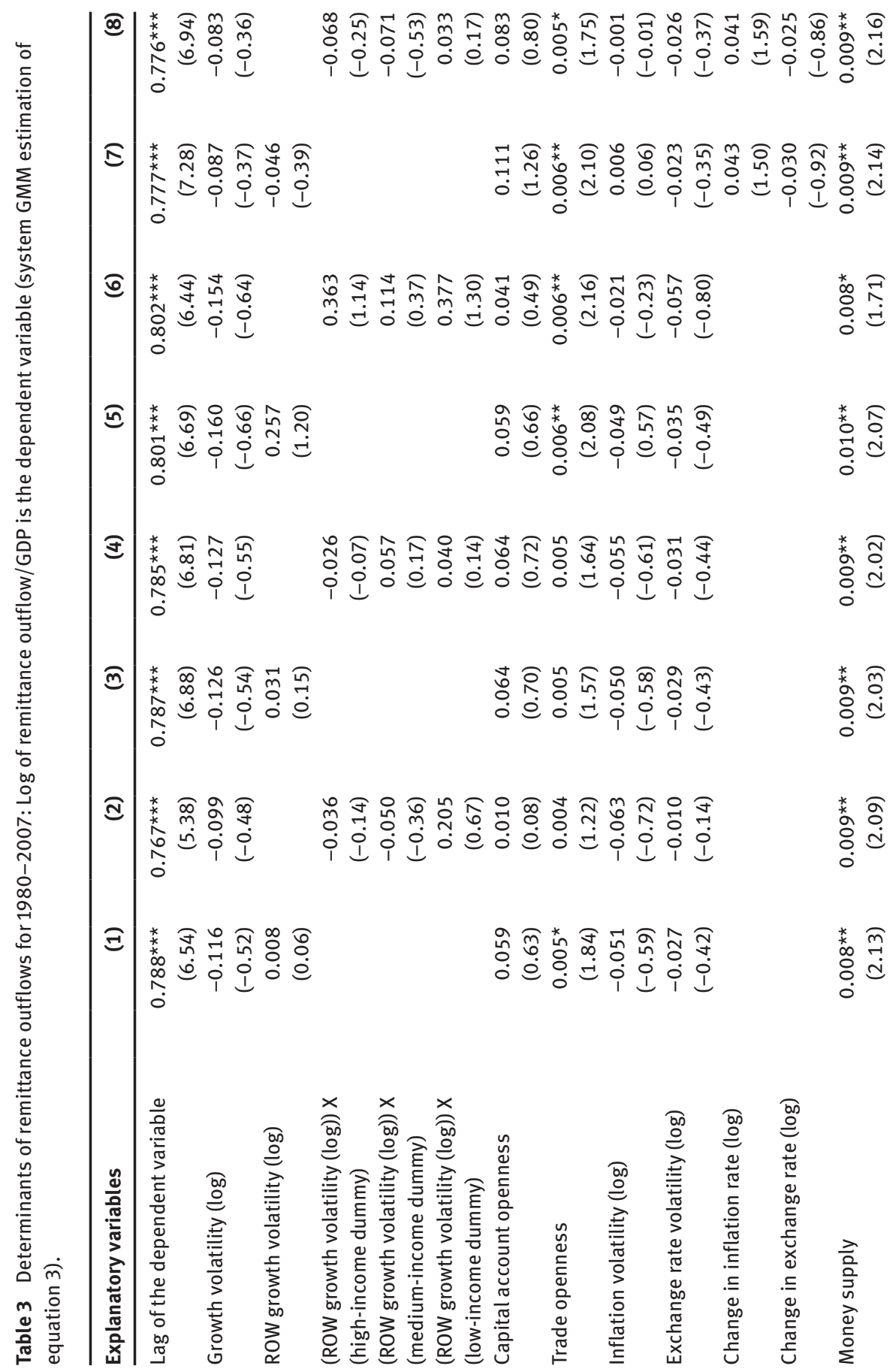




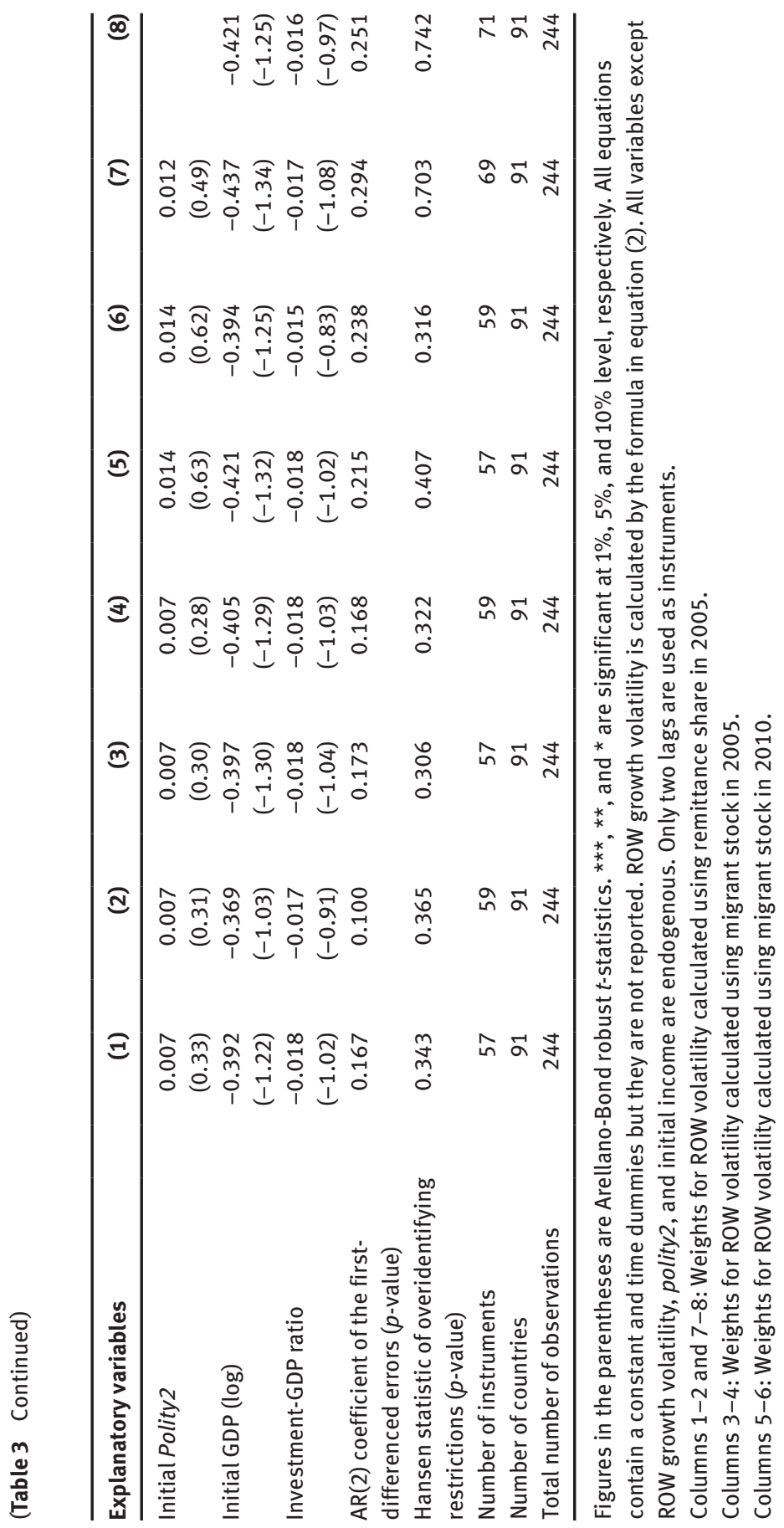




\subsection{Determinants of net remittance flows}

Finally, we investigate the determinants of net remittance flows. ${ }^{21}$ The number of countries further decreases because, as mentioned earlier, several countries report either remittance inflows or outflows. We consider only those countries for which net remittance flows are positive (its logarithm is used in the regression), and the 1980-2007 period is considered to reduce the number of instruments.

The results are presented in Table 4. The results show that trade and capital account openness significantly increase net remittance flows (columns 1 and 2). Net remittance flows decrease with the initial income level suggesting that poor countries are net remittance receivers. The growth volatility or ROW volatility cannot explain the net flows of remittances. The results are robust to different choices of the weight used to calculate the ROW volatility (columns 3-6), and inclusion of changes in inflation and exchange rate in the regression (columns 7 and 8).

The overall results suggest that remittance flows are influenced by macroeconomic conditions of both home and host countries.

\subsection{Robustness analysis}

There are fewer observations for the initial two intervals in the sample period. In addition, remittance flows are much higher in the middle-income compared to the other two income groups as documented in Table 1. We therefore re-estimate equation (3) for the period 1980-2007, and also separately for the middle-income countries which include the emerging economies. A few issues need to be mentioned for this choice of period and group of countries. We cannot conduct separate estimations for the low- and high-income countries because there are not enough countries in these two groups for estimation by the system-GMM method. The same is true for a separate analysis of the emerging economies. For remittance outflows and net flows, we previously estimated for the period 1980-2007; for these two dependent variables we now carry out the estimation only for the middle-income countries. For remittance inflows, we also carry out the estimation for the full set of countries.

The results are presented in Table 5. The results for remittance inflows are presented in columns 1-4. The results for the full set of countries (column 1) do not qualitatively change from those for the period 1970-2007. The coefficient of growth volatility is now larger at around -0.8 . The results for the middle-income

21 (Remittance inflows - Remittance outflows)/GDP. 


\begin{tabular}{|c|c|c|c|}
\hline ळ్ర & 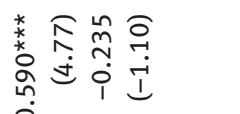 & \multicolumn{2}{|c|}{ 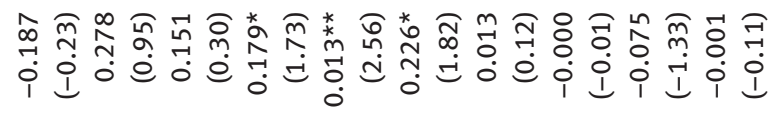 } \\
\hline$E$ & 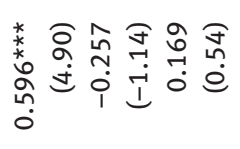 & 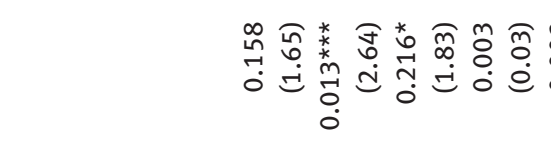 & $\begin{array}{ccc}0 \\
0 \\
0\end{array}$ \\
\hline$\widehat{\theta}$ & 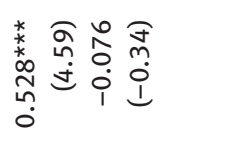 & 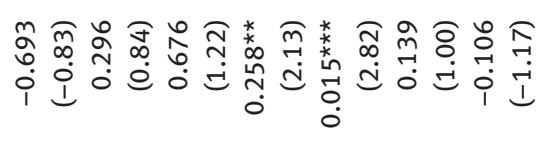 & $\begin{array}{l}\stackrel{t}{\circ} \\
\stackrel{0}{0} \\
\dot{i}\end{array}$ \\
\hline$\widetilde{\sigma}$ & 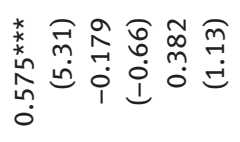 & 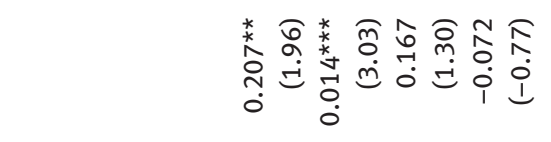 & \\
\hline$\Xi$ & 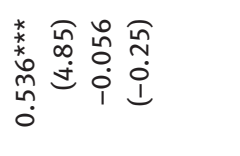 & 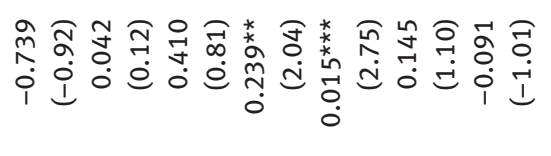 & \\
\hline$\widehat{\widetilde{\Xi}}$ & 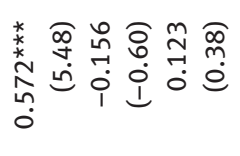 & 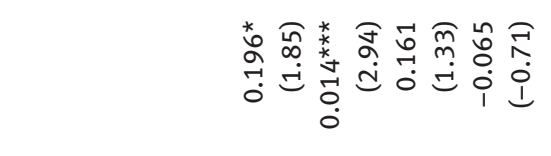 & \\
\hline$\widehat{\Xi}$ & 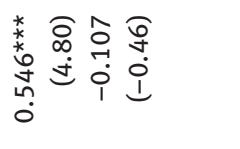 & 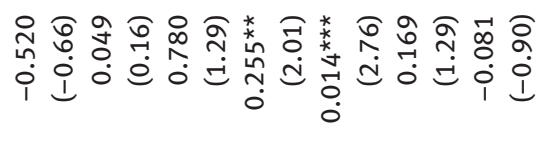 & $\begin{array}{l}\tilde{o} \\
\stackrel{0}{0} \\
\dot{i}\end{array}$ \\
\hline$\Xi$ & 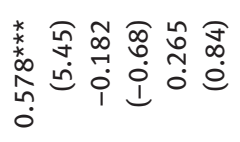 & 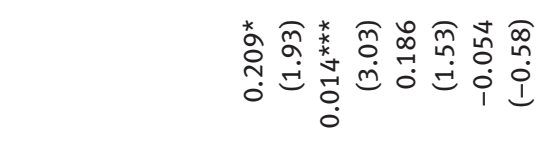 & \\
\hline
\end{tabular}

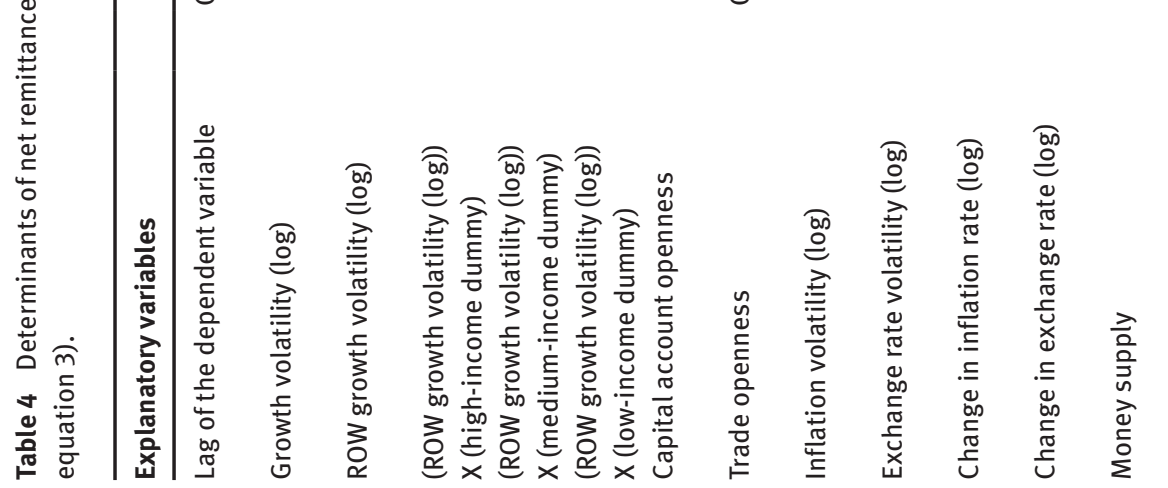




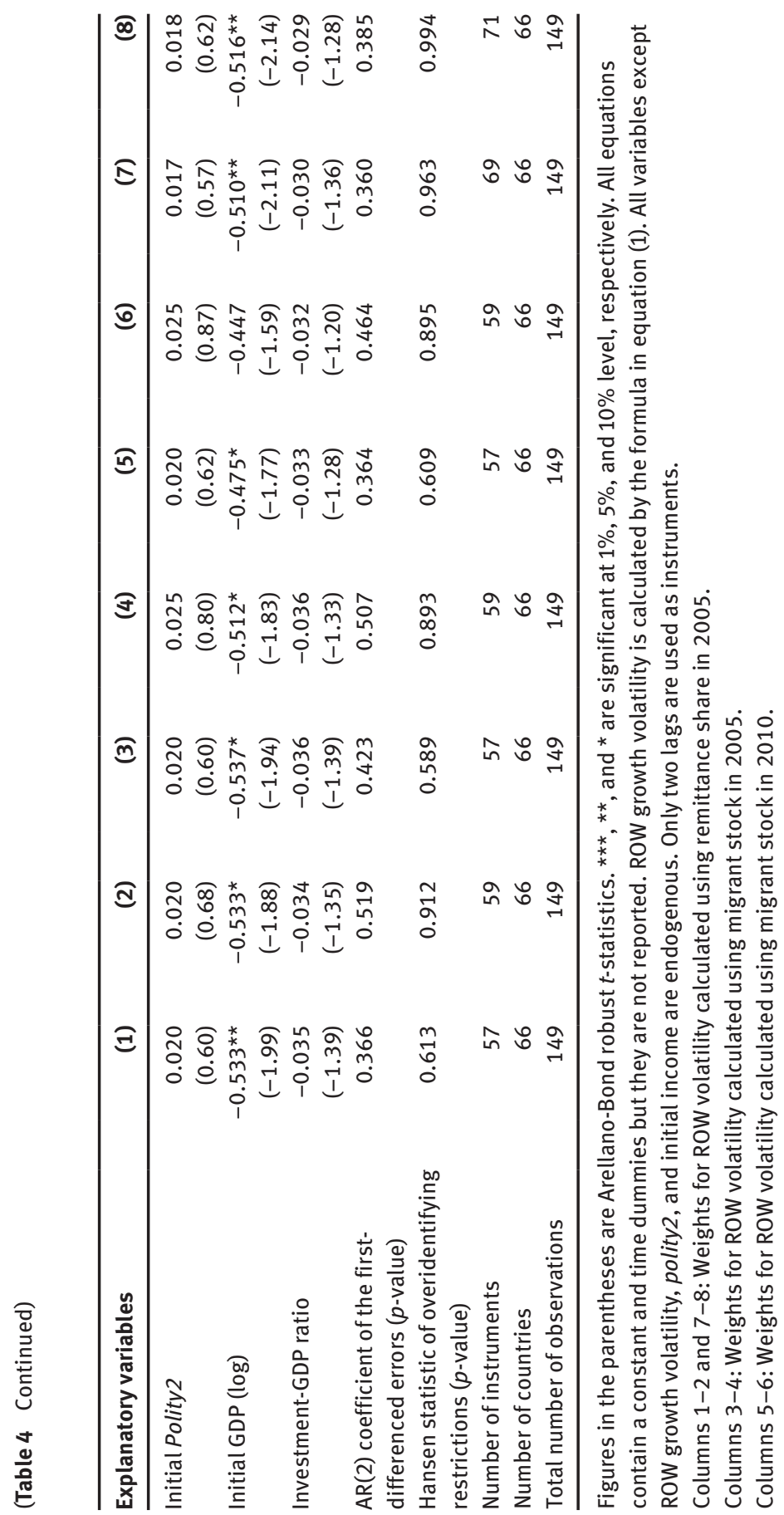




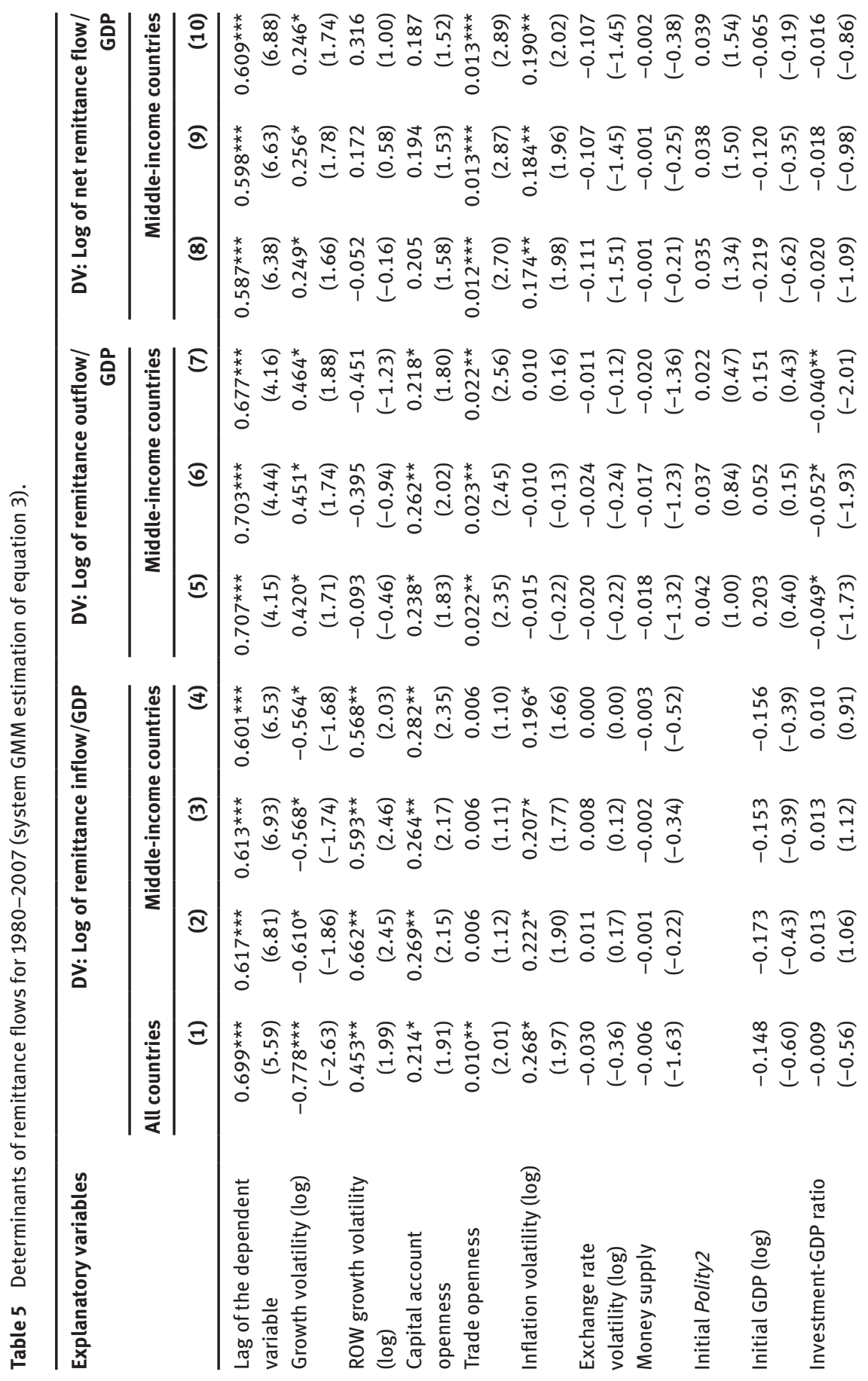




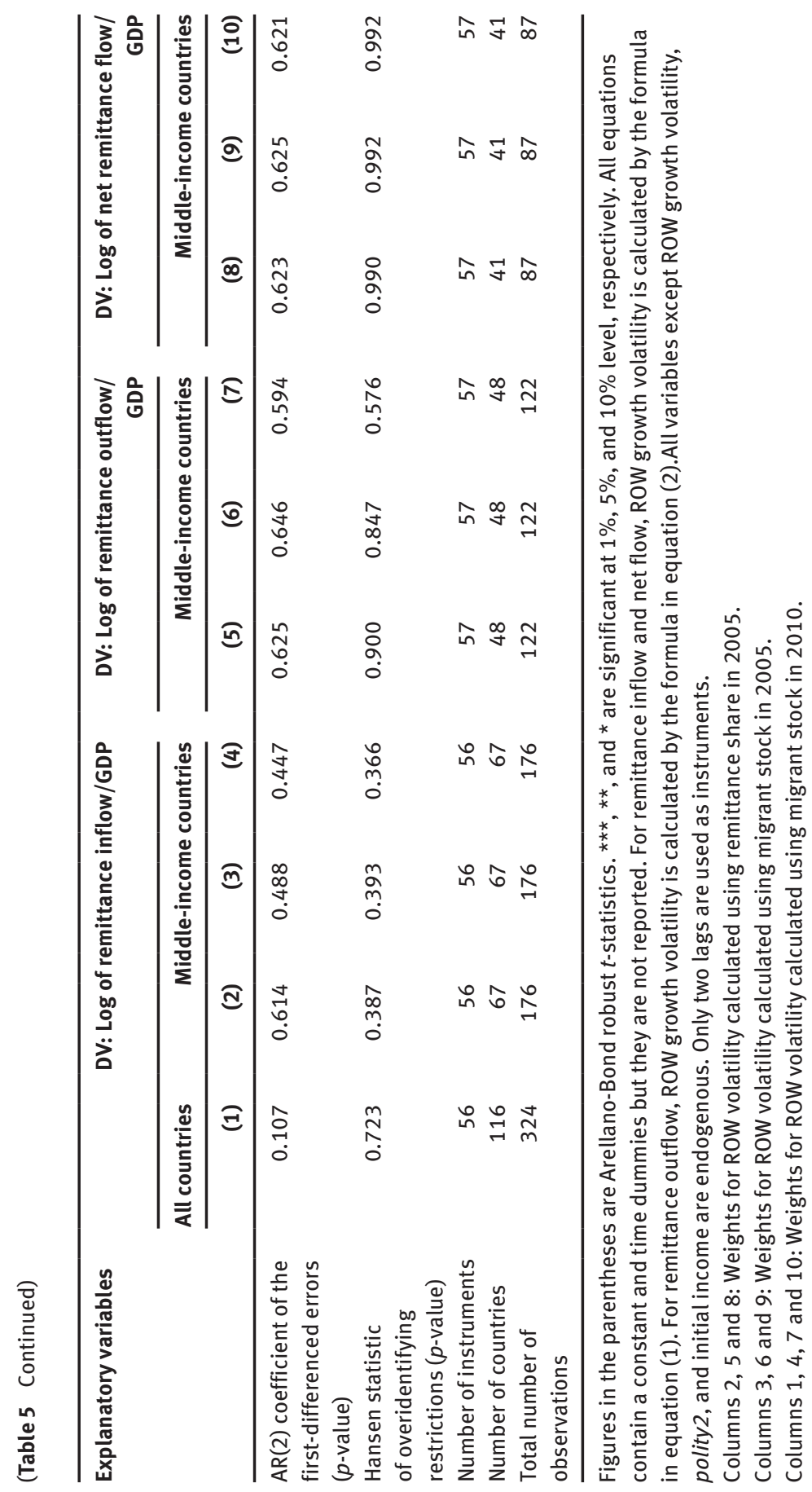


countries (columns 2-4) are also similar to that of the full sample with the only exception being that trade openness is insignificant.

The results for remittance outflows are presented in columns 5-7. There are significant differences in the results for the middle-income countries from that of the full sample. Growth volatility in host countries increases remittance outflows suggesting that economic uncertainty in host countries leads to larger remittance outflows. The coefficient of the investment-GDP ratio is negative and significant suggesting that lack of investment opportunities in host countries increase remittance outflows. These two results are complementary. Trade and capital account openness also increase remittance outflows. However, money supply now becomes insignificant. The results for net remittance flows are presented in columns 8-10; they do not qualitatively change from the results for the full sample with the only exception being that growth volatility is now significant. These results confirm that remittance flows are influenced by macroeconomic conditions of both home and host countries.

We now check for further robustness of our results by investigating if the significance of the ROW volatility is driven by the countries that constitute a large share to total remittance flows. For example, some host countries may contribute to a large share of total remittance inflows of home countries, and volatility in these host countries might disproportionately contribute to the ROW volatility. Similarly, there may be some home countries that might be the destination of a large share of total remittance outflows. In order to understand such influences, we disaggregate the ROW volatility in the remittance inflow (and net flow) equation by two country groups: i) top 10 host countries that are responsible for the largest remittance outflows, and ii) the remaining countries. This is done by multiplying the ROW volatility by the dummies for the above two groups of countries. ${ }^{22}$ This exercise is similar to the previous one that disaggregated the ROW volatility by three country income groups. Similarly, in the remittance outflow equation we disaggregate the ROW volatility by multiplying it by: i) dummies for the top 10 home countries that are destinations of the largest remittance inflows, and ii) the remaining countries. For simplicity, we estimate the equations only for the baseline ROW volatility index based on the remittance share in 2005. The results are presented in Table 6. Column 1 presents the results for remittance inflows, which are comparable to the results in column 1 in Table 2; column 2 presents the results for remittance outflows, which are comparable to the results in column 1 in Table 3; and column

22 The number of countries in each group is almost the same if the top 10\% host countries are chosen instead of the top 10. The results (not reported) do not meaningfully change from those reported in the table if the top $10 \%$ or even the top $5 \%$ of the sample of countries are chosen. The results also remain robust if changes in the inflation and exchange rate are included in the equations. 


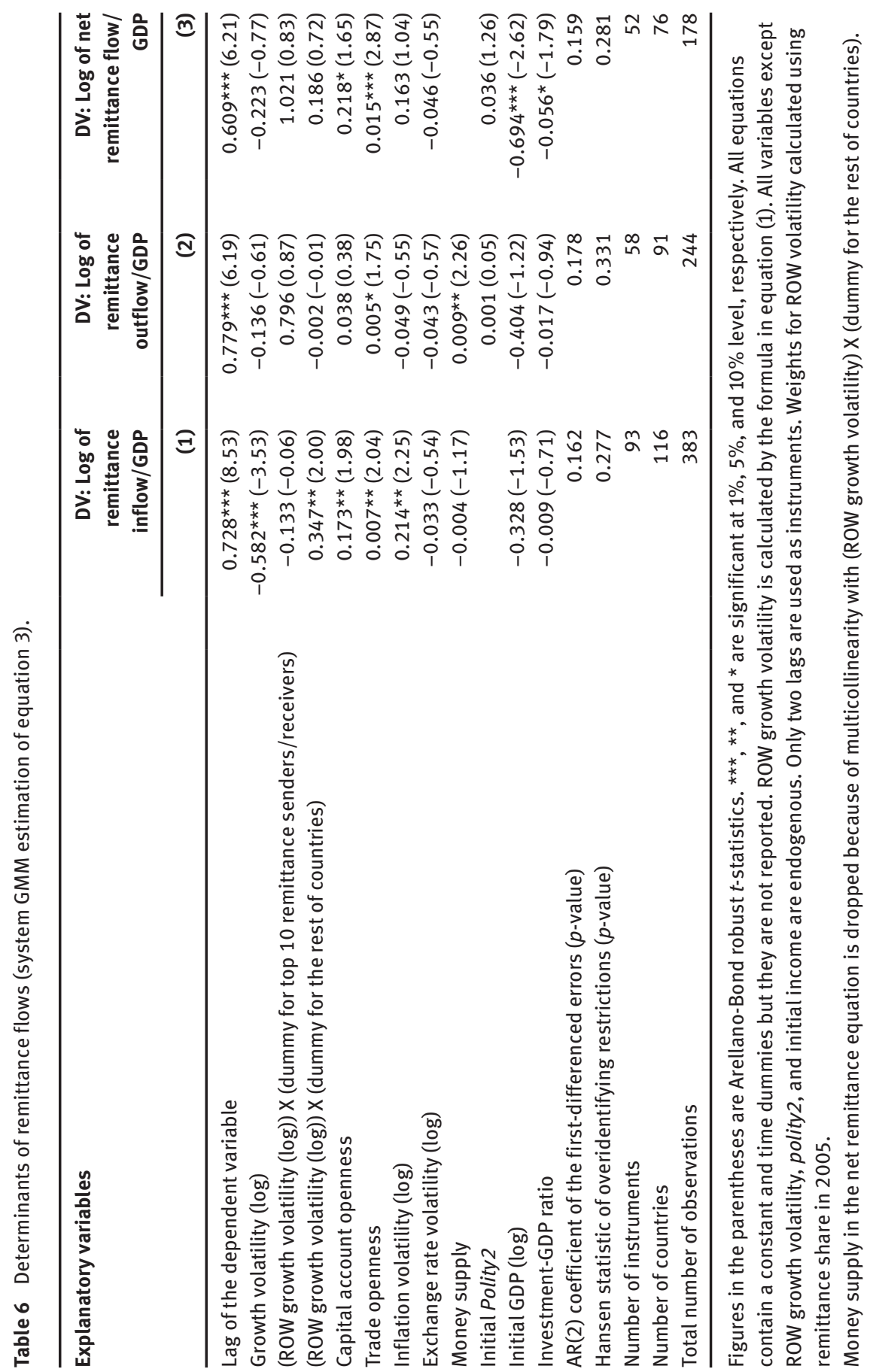


3 presents the results for net remittance flows, which are comparable to the results in column 1 in Table 4. The results show that the ROW volatility is insignificant for the top 10 host countries that are responsible for the largest remittance outflows. But it is significant for the rest of the countries with a magnitude (0.347) similar to the aggregate coefficient. In the case of remittance outflows and net flows, as before, the coefficient of the ROW volatility is insignificant for both groups of countries. In all cases, the magnitude and statistical significance of other coefficients do not also meaningfully change from the benchmark estimation, thus suggesting that our benchmark results are not driven by some outlier countries.

\section{Concluding remarks}

This paper investigates the macroeconomic determinants of remittance flows visà-vis the role of business cycle fluctuations in host countries. These two important issues have been ignored in the previous literature. The key innovation of the paper is to incorporate business cycle information of all host countries by constructing a rest-of-the-world volatility index for each home country. A separate model for remittance outflows has been estimated to understand the macroeconomic factors influencing remittance flows from host to home countries. The model is estimated by the dynamic panel system-GMM method. The results indicate that remittance inflows decrease with economic uncertainty in home countries but increase with economic uncertainty in host countries, especially for middle-income countries (i.e., remittance inflows are pro-cyclical to home country volatility but counter-cyclical to the volatility in host countries). The first result is consistent with the notion that remittances do not increase in the event of a negative shock, thus reducing their usefulness as a hedge against a negative shock in home countries. The latter result can be attributed to risk aversion of migrant workers (Amuedo-Dorantes and Pozo 2006). That is, migrants when faced with greater income uncertainty in the host country have the tendency to remit more back home. However, it must be noted that the motives for remittances are complex, especially at the cross-country level. Migrants remit for different reasons that also depend on individual migrant's characteristics in addition to both the host and home country characteristics, and aggregation at the crosscountry level may obscure the true motive.

The results also show that trade and capital account openness increase both remittance inflows and outflows. Lower interest rates in host counties cause remittance outflows. Remittance outflows are not related (acyclical) to the volatility in either home or host countries. However, a separate analysis of the middle-income 
countries indicates that remittance outflows increase with economic uncertainty and lack of investment opportunity in host countries. The results lead us to conclude that macroeconomic conditions of both home and host countries are important for understanding world remittance flows.

Acknowledgements: We would like to acknowledge Omar Bashar, Devashish Mitra, Bhaskara Rao, an anonymous referee and the participants at the 2011 Australasian Econometric Society Meeting for their helpful comments and suggestions. All errors and omissions are the sole responsibility of the author.

Received February 11, 2013; accepted August 25, 2013

\section{References}

Adams, R., and J. Page. 2003. “International Migration, Remittances and Poverty in Developing Countries." World Bank Policy Research Paper 3179, Washington DC.

Agarwal, R., and A. Horowitz. 2002. “Are International Remittances Altruism or Insurance? Evidence from Guyana Using Multiple-Migrant Households.” World Development 30: 2033-2044.

Akkoyunlu, S., and K. Kholodilin. 2008. “A Link Between Workers' Remittances and Business Cycles in Germany and Turkey.” Emerging Markets, Finance and Trade 44: 23-40.

Ambler, S., E. Cardia, and C. Zimmermann. 2004. “International Business Cycles: What are the Facts?." Journal of Monetary Economics 51: 257-276.

Amuedo-Dorantes, C., and S. Pozo. 2006. "Remittances as Insurance: Evidence from Mexican Immigrants.” Journal of Population Economics 19: 227-254.

Arellano, M., and S. Bond. 1991. "Some Tests of Specification for Panel Data: Monte Carlo Evidence and an Application to Employment Equations." Review of Economic Studies 58: 277-297.

Arellano, M., and 0. Bover. 1995. “Another Look at the Instrumental Variable Estimation of Error-components Models.” Journal of Econometrics 68: 29-51.

Banerjee, B. 1984. "The Probability, Size and Uses of Remittances from Urban to Rural Areas in India." Journal of Development Economics 16: 293-311.

Barajas, A., R. Chami, C. Fullenkamp, and A. Garg. 2010. "The Global Financial Crisis and Workers' Remittances to Africa: What's the Damage?.” IMF Working Paper 10/24, Middle East and Central Asia Department.

Blundell, R., and S. Bond. 1998. "Initial Conditions and Moment Restrictions in Dynamic Panel Data Models.” Journal of Econometrics 87: 115-143.

Bugamelli, M., and F. Paternò. 2011. “Output Growth Volatility and Remittances.” Economica 78 (311): 480-500.

Cavalcanti, T. V., K. Mohaddes, and M. Raissi. 2012. “Commodity Price Volatility and the Sources of Growth." IMF Working Paper 12, Washington DC.

Chami, R., A. Barajas, T. Cosimano, C. Fullenkamp, M. Gapen, and P. Montiel. 2008. “Macroeconomic Consequences of Remittances.” IMF Occasional Paper 259. 
Chami, R., D. Hakura, and P. Montiel. 2009. "Remittances: An Automatic Output Stabilizer?." IMF Working Papers: 91/2009, International Monetary Fund.

Chinn, M. D., and H. Ito. 2008. "A New Measure of Financial Openness.” Journal of Comparative Policy Analysis 10 (3): 309-322.

de la Brière, B., E. Sadoulet, A. de Janvry, and S. Lambert. 2002. "The Roles of Destination, Gender, and Household Composition in Explaining Remittances: An analysis for the Dominican Sierra." Journal of Development Economics 68: 309-328.

Durdu, C. B., and S. Sayan. 2008. "Emerging Market Business Cycles with Remittance Fluctuations.” International Finance Discussion Papers 946, Board of Governors of the Federal Reserve System, US.

Dustmann, C. 1997. "Return Migration, Uncertainty and Precautionary Savings." Journal of Development Economics 52: 295-316.

El Sakka, M. I. T. and R. McNabb. 1999. "The Macroeconomic Determinants of Emigrant Remittances.” World Development 27: 1493-1502.

Faini, R. 1994. "Workers Remittances and the Real Exchange Rate: A Quantitative Framework." Journal of Population Economics 7: 235-245.

Frankel, J. A. 2009. “Are Bilateral Remittances Countercyclical?.” NBER Working Paper 15419, Massachusetts, Cambridge.

Galor, O., and O. Stark. 1990. "Migrants' Savings, the Probability of Return Migration and Migrants' Performance.” International Economic Review 31: 463-467.

Giuliano, P., and M. Ruiz-Arranz. 2009. "Remittances, Financial Development and Growth." Journal of Development Economics 90: 144-152.

Gupta, P. 2005. “Macroeconomic Determinants of Remittances: Evidence from India.” IMF Working Paper No. 2224.

Higgins, M., A. Hysenbegasi, and S. Pozo. 2004. "Exchange-Rate Uncertainty and Workers' Remittances." Applied Financial Economics 14: 403-411.

Hnatkovska, V., and N. Loayza. 2005. "Volatility and growth." In Managing Economic Volatility and Crises: A Practitioner's Guide, edited by Joshua Aizenman and Brian Pinto, 65-100. New York: Cambridge University Press.

Hoddinott, J. 1994. "A Model of Migration and Remittances Applied to Western Kenya." Oxford Economic Papers 46: 459-476.

Hodrick, R., and E. C. Prescott. 1997. "Postwar US Business Cycles: An Empirical Investigation.” Journal of Money, Credit, and Banking 29 (1): 1-16.

Jackman, M., R. Craigwell, and W. Moore. 2009. "Economic Volatility and Remittances: Evidence from SIDS." Journal of Economic Studies 36: 135-146.

Kapur, D. 2005. “Remittances: the New Development Mantra?.” In Remittance Development Impact and Future Prospects, edited by S. Maimbo and D. Ratha, Washington: World Bank.

Kneller, R., and G. Young. 2001. "Business Cycle Volatility, Uncertainty and Long-run Growth.” Manchester School 69: 534-552.

Lane, P. R., and G. M. Milesi-Ferretti. 2007. "The External Wealth of Nations Mark II: Revised and Extended Estimates of Foreign Assets and Liabilities, 1970-2004." Journal of International Economics 73: 223-250.

Lianos, T. 1997. “Factors Determining Migrant Remittances: The Case of Greece.” International Migration Review 31: 72-87.

Lucas, R., and O. Stark. 1985. “Motivations to Remit: Evidence from Botswana." Journal of Political Economy 93: 901-918.

Lueth, E., and M. Ruiz-Arranz. 2008. "Determinants of Bilateral Remittance Flows.” The B.E. Journal of Macroeconomics 8: Article 26. 
Martin, P., and C. A. Rogers. 2000. “Long-term Growth and Short-term Economic Stability.” European Economic Review 44: 359-381.

Mundaca, B. G. 2009. "Remittances, Financial Market Development, and Economic Growth: The Case of Latin America and the Caribbean." Review of Development Economics 13: 288-2009.

Neagu, I. C., and M. Schiff. 2009. "Remittance Stability, Cyclicality and Stabilizing Impact in Developing Countries.” World Bank Policy Research Working Paper No. 5077.

Polity IV Project (2012): Political Regime Characteristics and Transitions, 1800-2007, http:// www.systemicpeace.org/polity/polity4.htm.

Ramey, G., and V. Ramey. 1995. “Cross-Country Evidence on the Link between Volatility and Growth.” American Economic Review 85: 1138-1151.

Rapoport, H., and F. Docquier. 2006. “The Economics of Migrants' Remittances.” In Handbook of the Economics of Giving, Altruism and Reciprocity, edited by S.-C. Kolm and J. M, Ythier, vol. 2, 1135-1198. The Netherlands: North Holland.

Ratha, D. 2005. “Workers' Remittances: An Important and Stable Source of External Development Finance.” Economics Seminar Series Paper 9, St. Cloud State University.

Ratha, D., and W. Shaw. 2007. "South-South Migration and Remittances." Development Prospects Group, World Bank (data updated in 2010).

Ravn, M. O., and H. Uhlig. 2002. "On Adjusting the Hodrick-Prescott Filter for the Frequency of Observations." Review of Economics and Statistics 84: 371-380.

Roberts, K., and M. Morris. 2003. "Fortune, Risk and Remittances: An Application of Option Theory to Participation in Village-Based Migration Networks." International Migration Review 37: 1252-1281.

Roodman, D. 2006. "How to Do xtabond2: An Introduction to "Difference" and "System" GMM in Stata." Working Paper No. 103, The Center for Global Development.

Rosenzweig, M. R. 1988. "Risk, Implicit Contracts and the Family in Rural Areas of Low-Income Countries.” Economic Journal 98: 1148-1170.

Sayan, S., and A. Tekin-Koru. 2008. "The Effects of Economic Developments and Policies in Host Countries on Workers' Remittance Receipts of Developing Countries: The Cases of Turkey and Mexico Compared." In The Impact of Rich Country Policies on Developing Economies, edited by R. Lucas, L. Squire and T. Srinivasan, London: Edward Elgar.

Sayan, S. 2004. "Guest Workers' Remittances and Output Fluctuations in Host and Home Countries: The Case of Remittances from Turkish Workers in Germany." Emerging Markets Finance and Trade 40: 68-81.

Stark, O., and D. Lehvari. 1982. "On Migration and Risk in LDCs." Economic Development and Cultural Change 31: 191-196.

Stark, O., and R. Lucas. 1988. "Migration, Remittances and the Family." Economic Development and Cultural Change 36: 465-481.

Vargas-Silva, C. 2008. "Are Remittances Manna from Heaven? A Look at the Business Cycle Properties of Remittances." North American Journal of Economics and Finance 19: 290-303.

Vargas-Silva, C., and P. Huang. 2006. "Macroeconomic Determinants of Workers' Remittances: Host versus Home Country's Economic Conditions.” Journal of International Trade and Economic Development 15: 81-99.

World Bank (2009): http://econ.worldbank.org/WBSITE/EXTERNAL/EXTDEC/EXTDECPROSPEC TS/0,,contentMDK:21121930 menuPK:3145470 pagePK:64165401 piPK:64165026 th eSitePK:476883,00.html 